\title{
DAMPAK PERATURAN TENTANG IMPOR BERAS TERHADAP KEGAGALAN KETAHANAN PANGAN DAN KEMISKINAN PETANI DI INDONESIA
}

\author{
Sulhani Hermawan ${ }^{1}$
}

\begin{abstract}
Rice import in Indonesia is supported by some legal regulations, with the reason of supporting food saving and making food sovereignity. However, in fact, because of rice import, food sovereignity decrease gradually and the farmers become more poor. This article study critically some regulations in Indonesia on rice import. The regulations don't support welfare state of Indonesia, but become the trigger of poor scale of farmers, who are majority of citizen in Indonesia. So, the regulations of rice import are in contrary with Constitution in Indonesia and Pancasila.
\end{abstract}

Keyword: rice import, regulations, farmer

\begin{abstract}
Abstrak
Impor beras di Indonesia didukung oleh ketentuan perundang-undangan dengan alasan untuk menjaga ketahanan pangan dan kedaulatan pangan. Namun pada kenyataannya, impor beras mengakibatkan kedaulatan pangan menjadi menurun secara bertahap and petani menjadi miskin. Tulisan ini merupakan studi kritis terhadap peraturan perundang-undangan Indonesia mengenai impor beraas. Peraturan perundang-undangan tidak mendukung Indonesia menjadi negara sejahtera tapi menjadi pemicu bagi kemiskinan bagi petani, sebagai mayoritas penduduk Indonesia. Maka peraturan perundangundangan mengenai impor beras bertentangan dengan UUD Indonesia dan Pancasila.
\end{abstract}

Kata kunci: impor beras, peraturan, petani

\section{Pendahuluan}

Impor beras oleh pemerintah Indonesia menjadi fenomena yang mencolok akhir-akhir ini, dengan semua akibat dan konsekuensinya, pro dan kontranya. Pada tahun 2010, misalnya, Menko Perekonomian Hatta Rajasa mengatakan bahwa hingga akhir bulan Desember sebanyak 500 ribu ton beras impor akan masuk Indonesia. "Secara Goverment to Goverment kita masukan 1

${ }^{1}$ Penulis adalah Staf Pengajar pada Fakultas Syariah dan Ekonomi Islam, Institut Agama Islam Negeri (IAIN) Surakarta, peserta Program S-3 Ilmu Hukum UGM Yogyakarta (masuk tahun 2010). Alamat kontak: sulhanihermawan@yahoo.com. 
juta ton, bulan ini 500 ribu ton masuk," ujar Hatta sebelum sidang kabinet paripurna di kantor Kepresidenan Jakarta, Jumat tanggal 17 Desember 2010. Hatta menambahkan, selain menjaga stok pangan nasional, pemerintah bertujuan untuk menekan laju kenaikan harga beras. ${ }^{2}$

Bulog telah melakukan kesepakatan tentang volume impor dengan Vietnam dan Thailand, yaitu sebesar 1.080.000 ton. Beras dari Thailand itu akan langsung digelontorkan ke pasar untuk meredam gejolak harga menjelang akhir tahun $2010 .^{3}$ Impor beras dari Thailand yang dilakukan Bulog kali ini, kata Menteri Pertanian Suswono, untuk melindungi petani dari kerugian petani. Di mana jika harga jual petani di bawah Harga Pembelian Pemerintah (HPP) maka Bulog diwajibkan untuk membelinya, sedangkan jika harga HHP jauh lebih mahal maka Bulog dapat membeli ke negara luar. "Mengingat beras yang diserap Bulog dari petani saat ini masih sangat kecil, pertama karena kualitas beras petani tahun ini banyak yang di bawah standar, kedua harga beras petani saat ini di atas harga pembelian pemerintah," kata Menteri Pertanian (Mentan) Suswono, saat melakukan kunjungan kerja ke Kabupaten Musi Rawas, Sumsel, Rabu 15 Desember 2010. ${ }^{4}$

Persediaan stok beras Bulog hingga akhir 2010 sebanyak 1,7 juta ton yang tidak terpenuhi dengan rendahnya penyerapan beras petani oleh Bulog, mengharuskan adanya impor beras yang bertujuan menjaga stabilitas harga beras bagi masyarakat miskin perkotaan. Stok beras yang disediakan pemerintah tersebut, kata Mentan Suswono, bertujuan menstabilkan harga jual beras di dalam negeri, sehingga nantinya dapat dijangkau dan melindungi petani dari kerugian. ${ }^{5}$

\section{Peraturan Perundang-Undangan tentang Impor Beras dan Soal Ketahanan Pangan}

Membahas kebijakan pemerintah terkait dengan impor beras, maka ada sejumlah aturan hukum di Indonesia yang mengatur tentang kebijakan impor beras yang banyak dikaitkan dengan ketahanan pangan. Undang-Undang yang mengatur tentang Pangan di Indonesia, yaitu Undang-Undang No. Nomor 7 tahun 1996 menyebutkan bahwa Pemerintah menyelenggarakan pengaturan, pembinaan, pengendalian dan pengawasan, sementara masyarakat menyelenggarakan proses produksi dan penyediaan, perdagangan, distribusi

\footnotetext{
${ }^{2}<$ http://arsipberita.com/show/impor-beras-bulan-ini-capai-500-ribu-ton-120642.html>, diakses tanggal 24 Novermber 2011.

$3<$ http://arsipberita.com/show/bulog-masih-bayar-bea-impor-beras-rp450-per-kg122300. html>, diakses tanggal 24 Novermber 2011.

$4<\mathrm{http}: / /$ arsipberita.com/show/mentan-impor-beras-untuk-jaga-stabilitas-pangan118997.html>, diakses tanggal 24 Novermber 2011.

${ }^{5}$ Ibid.
} 
serta berperan sebagai konsumen yang berhak memperoleh pangan yang cukup dalam jumlah dan mutu, aman, bergizi, beragam, merata, dan terjangkau oleh daya beli mereka. ${ }^{6}$

Peraturan Pemerintah No.68 Tahun 2002 tentang Ketahanan Pangan sebagai peraturan pelaksanaan UU No.7 tahun 1996 menegaskan bahwa untuk memenuhi kebutuhan konsumsi yang terus berkembang dari waktu ke waktu, upaya penyediaan pangan dilakukan dengan mengembangkan sistem produksi pangan yang berbasis pada sumber daya, kelembagaan, dan budaya lokal, mengembangkan efisiensi sistem usaha pangan, mengembangkan teknologi produksi pangan, mengembangkan sarana dan prasarana produksi pangan dan mempertahankan dan mengembangkan lahan produktif. Di samping itu, PP ini juga mengatur tentang kerjasama internasional yang dilakukan dalam bidang produksi, perdagangan dan distribusi pangan, cadangan pangan, pencegahan dan penanggulangan masalah pangan serta riset dan teknologi pangan. ${ }^{7}$

Keputusan Presiden No. 132 tahun 2001 tentang Dewan Ketahanan Pangan, Pemerintah membentuk Dewan Ketahanan Pangan ( DKP) diketuai oleh Presiden RI dan Menteri Pertanian sebagai Ketua Harian DKP. DKP terdiri dari 13 Menteri dan 2 Kepala LPND. Dalam pelaksanaan sehari-hari, DKP dibantu oleh Badan Bimas Ketahanan Pangan Deptan, Tim Ahli Eselon I Menteri Terkait (termasuk Staf Ahli Bidang Pangan KRT), Tim Teknis dan Pokja. ${ }^{8}$

Peraturan Presiden Republik Indonesia No. 83 tahun 2006 menunjuk Kepres No. 132 tahun 2001, mengatur optimalisasi dan penyesuaian fungsi dan tugas DKP dengan perkembangan keadaan. Perpres ini mengatur bahwa DKP memiliki tugas membantu Presiden merumuskan kebijakan dan melakukan evaluasi serta pengendalian dalam rangka mewujudkan ketahahanan pangan nasional. ${ }^{9}$ Bidang tugas dewan tersebut adalah kegiatan penyediaan pangan, distribusi pangan, cadangan pangan, penganekaragaman pangan, pencegahan dan penanggulangan masalah pangan dan gizi. ${ }^{10}$ Dewan Ketahanan Pangan menurut Perpres ini (pasal 3 ayat 1) diketuai oleh Presiden dengan ketua harian Menteri Pertanian dan beranggotakan 16 Menteri, termasuk Menteri Perdagangan dan Kepala BPS dan Kepala BPPOM. ${ }^{11}$ Perpres ini juga

${ }^{6}$ Lemlit UGM, "Ketahanan Pangan" hal. 1, dalam <lemlit.ugm.ac.id/Agro/download/ white paper.doc>, diakses tanggal 24 Novermber 2011.

\footnotetext{
${ }^{7}$ Ibid.

${ }^{8}$ Ibid., hal. 2.

${ }^{9}$ Pasal 2 ayat 1 Perpres No. 83 tahun 2006.

${ }^{10}$ Pasal 2 ayat 2 Perpres No. 83 tahun 2006.

${ }^{11}$ Pasal 3 ayat 1 Perpres No. 83 tahun 2006.
} 
memberikan kekuasaan kepada Gubernur untuk membentuk DKP Propinsi ${ }^{12}$ dan Bupati/Walikota untuk membentuk DKP Kabupaten/Kota. ${ }^{13}$

Selama dua tahun terakhir ini, secara jelas ada dua peraturan yang dikeluarkan oleh pemerintah tentang impor dan ekspor beras yaitu Peraturan Menteri Perdagangan (Permendag) No. 12 tahun 2008 dan Permendag No. 14 tahun 2009 (yang mengubah aturan tentang ekspor beras dalam Bab V Permendag No. 12 tahun 2008). Membaca aturan tentang impor beras tersebut, sebagaimana dinyatakan dalam aturan tersebut, bahwa kebijakan impor beras diambil untuk mencapai tujuan utama ketahanan pangan ${ }^{14}$ sebagaimana diatur oleh UU No. 7 tahun 1996 tentang Pangan. Impor beras terdiri dari tiga jenis yang berbeda sesuai dengan tujuannya masing-masing dengan aturan yang berbeda.

Pertama, impor beras yang dilakukan untuk stabilisasi harga, penanggulangan keadaan darurat, masyarakat miskin dan kerawanan pangan hanya dapat dilakukan oleh Perusahaan Umum Badan Usaha Logistik (Perum Bulog) di luar masa 1 bulan sebelum panen raya, masa panen raya dan dua bulan setelah panen raya, dan penentuan masa panen raya ditentukan oleh Menteri Pertanian. ${ }^{15}$ Aturan waktu impor beras dapat dikecualikan apabila impor beras pada tujuan pertama dilakukan oleh Menteri Perdagangan. ${ }^{16}$

Kedua, impor beras yang hanya dapat dilakukan oleh importir tertentu yang disetujui oleh Dirjen Perdagangan Luar Negeri, Departemen Perdagangan atas nama Menteri Perdagangan. ${ }^{17}$ Impor jenis ini dilakukan untuk keperluan tertentu yang terkait dengan kesehatan/dietary dan konsumsi khusus/segmen tertentu serta untuk pengadaan benih. ${ }^{18}$ Keperluan tertentu juga memuat tujuan untuk memenuhi kebutuhan industri sebagai bahan baku/penolong yang berasnya tidak atau belum sepenuhnya dihasilkan di dalam negeri. ${ }^{19}$ Beras jenis ini dilarang diperjualbelikan atau dipindahtangankan ${ }^{20}$ dan hanya dapat dilakukan oleh importir yang diakui sebagai Importir Produsen (IP) Beras dari

${ }^{12}$ Bab II Perpres No. 83 tahun 2006.

${ }^{13}$ Bab III Perpres No. 83 tahun 2006.

${ }^{14}$ Konsideran menimbang poin b 2 Permendag No. 12 tahun 2008.

${ }^{15}$ Pasal 3 ayat 2 dan 3 Permendag No. 12 tahun 2008.

${ }^{16}$ Pasal 3 ayat 4 Permendag No. 12 tahun 2008.

${ }^{17}$ Pasal 5 ayat 2 dan 3 Permendag No. 12 tahun 2008.

${ }^{18}$ Pasal 5 ayat 1 Permendag No. 12 tahun 2008.

${ }^{19}$ Pasal 7 ayat 1 Permendag No. 12 tahun 2008.

${ }^{20}$ Pasal 7 ayat 2 Permendag No. 12 tahun 2008 
Dirjen Perdagangan Luar Negeri, Departemen Perdagangan atas nama Menteri Perdagangan. $^{21}$

Ketiga, impor beras yang bersumber dari hibah adalah beras lain-lain dengan kriteria tertentu, 22 hanya dapat dilakukan oleh lembaga/organisasi sosial atau badan pemerintah setelah mendapat persetujuan impor dari Dirjen Perdagangan Luar Negeri, Departemen Perdagangan atas nama Menteri Perdagangan. $^{23}$ Impor dari hibah tersebut dilakukan untuk keperluan penanggulangan bencana atau bukan penanggulangan bencana dengan rencana pendistribusian yang diketahui oleh Menteri Sosial atau Pejabat yang ditunjuk. $^{24}$

Dalam bahasa peraturan tentang impor beras di atas, kebijakan impor beras dinyatakan sebagai kebijakan dalam semangat ketahanan pangan di Indonesia. Peraturan tentang impor beras digunakan untuk keberlangsungan kepentingan negara secara tertib dalam mewujudkan ketahanan pangan, meningkatkan produksi pasar beras dan sekaligus meningkatkan pendapatan negara secara terus-menerus. Di samping itu, peraturan tentang impor beras dengan semua pasal dan ayatnya yang memberikan batasan dalam impor beras, dan peraturan lain yang berada di atas peraturan tersebut, diharapkan bisa mencegah konflik antara konsumen beras kelompok miskin, konsumen beras segmen tertentu, lembaga sosial atau pemerintah tertentu, dan pengguna beras pada industri tertentu dengan petani Indonesia penanam padi. Peraturan tentang impor beras juga diharapkan bisa mencegah konflik antara para importir beras yang terdiri dari Bulog, Menteri Perdagangan, badan pemerintah dan lembaga sosial, perusahaan swasta pengimpor beras, dan perusahan industri tertentu pengguna beras dalam produksinya.

Meskipun demikian, aturan-aturan tentang impor beras tersebut dinilai bersifat responsif terhadap kelompok importir besar dan berkuasa (Menteri Perdagangan, importir yang mengantongi ijin dan memenuhi syarat tertentu, Bulog, kelompok pengusaha industri tertentu dan segmen konsumen beras tertentu). Di sisi yang lain, aturan tentang impor beras juga bersifat represif terhadap petani penanam beras Indonesia (panen raya ditentukan waktunya oleh Menteri Pertanian, ada pengecualian bagi impor oleh Menteri Perdagangan), importir kecil dan lemah (tidak diperkenankan melakukan impor) serta konsumen beras secara umum (harga beras tergantung kepada harga impor). Pandangan sedemikian ini mewakili pandangan kelompok strukturalis dalam sosiologi hukum.

\footnotetext{
${ }^{21}$ Pasal 7 ayat 3 Permendag No. 12 tahun 2008.

${ }^{22}$ Pasal 8 ayat 1 Permendag No. 12 tahun 2008.

${ }^{23}$ Pasal 9 ayat 1 Permendag No. 12 tahun 2008

${ }^{24}$ Pasal 9 ayat 2 Permendag No. 12 tahun 2008.
} 


\section{Kelompok Strukturalis Pendukung Peraturan Impor Beras}

Kelompok strukturalis yang menekankan pentingnya identifikasi dan analisis "struktur dalam" yang mendasari dan menghasilkan fenomena yang dapat diobservasi, ${ }^{25}$ memandang bahwa hukum adalah alat negara untuk mewujudkan kepentingannya (berupa keberlangsungan ekonomi kapitalistik). Pada dasarnya, peraturan impor beras merupakan seperangkat alat yang digunakan oleh negara untuk mendukung upaya menjaga ketersediaan cadangan pangan nasional.

Dalam analisis strukturalis lainnya, diyakini bahwa hukum digunakan juga untuk mencegah konflik antara kelompok kontributif versus kelompok non kontributif dan antar kelompok kontributif yang menjadi penghambat. Hukum yang dikeluarkan oleh negara dengan otonomi yang relatif, dibuat untuk menjaga keberlangsungan ekonomi kapitalistik dengan usaha yang berlangsung tertib, peningkatan produksi terus-menerus dan peningkatan pendapatan negara. ${ }^{26}$ Dalam hal ini, pendukung impor beras dari kalangan pemerintah menyatakan bahwa aturan tentang impor beras dibuat untuk menjaga ketertiban dalam perdagangan beras, terutama terkait dengan pedagang beras internasional dan kepentingan lembaga negara dalam menyediakan cadangan pangan bagi konsumen beras di Indonesia.

Aliran strukturalis yang berargumen bahwa sebuah wilayah budaya yang khusus hanya bisa dipahami dengan sebuah struktur (dimodelkan dalam bahasa) yang terpisah baik dari organisasi realitas maupun idea-idea atau imajinasi tentang "tatanan ketiga", 27 berasumsi bahwa pembentuk hukum dihadapkan pada kendala yang didesakkan oleh negara \& kelompok sosial. Kedudukan negara relatif otonom berhadapan dengan kelompok-kelompok sosial. Konsekuensinya, hukum mencerminkan kepentingan negara sendiri dengan membuka masuknya kepentingan kelompok sosial yang kontributif terhadap kepentingan negara. Hukum memiliki dua karakter yang berbeda, bersifat responsif terhadap kelompok kontributif dan bersifat represif terhadap kelompok non-kontributif. ${ }^{28}$ Althusser, yang merupakan strukturalis marxist, berpendapat bahwa tatanan struktural dari mode produksi kaum kapitalis terpisah dari kelompok-kelompok aktual dan riil yang terlibat di dalam

${ }^{25}$ Tom Bottomore, "Strusturalism", dalam William Outhwaite (ed.), "Kamus Lengkap Pemikian Sosial Modern (The Blckwell Dictionary of Modern Social Thought)", Ed. 2. Cet. 1, (Jakarta: Kencana 2008), hal. 852.

${ }^{26}$ Nurhasan Ismail, "Bahan Kuliah Sosiologi Hukum Bagi Magister Hukum UGM", dipublikasikan terbatas dalam bentuk file power point, hal. 32-33.

${ }^{27}$ Deleuze, Gilles, "How Do We Recognise Structuralism?" dalam Desert Islands and Other Texts 1953-1974. Penterjemah. David Lapoujade., Editor. Michael Taormina. Los Angeles and New York: Semiotext(e): 2004, hal. 171-173 yang dikutip dalam <http://en.wikipedia.org/wiki/Structuralism>, diakses tanggal 19 Oktober 2011.

28 Nurhasan Ismail, "Bahan Kuliah Sosiologi Hukum Bagi Magister Hukum Sekolah Pascasarjana UGM", dipublikasikan terbatas dalam bentuk file power point, hal. 17. 
hubungan dengannya dan juga terpisah dari bentuk-betuk ideologi yang digunakan untuk memahami hubungan tersebut. ${ }^{29}$ Dengan argumen ini, kelompok pendukung aturan tentang impor beras menyatakan bahwa negara tidak bisa ditekan oleh siapapun, baik dari dalam maupun dari luar negeri dalam menentukan aturan tentang perberasan, khususnya impor beras untuk mendukung ketahanan pangan di Indonesia.

\section{Mistifikasi di Balik Aturan Impor Beras dan Kesejahteraan Petani Penanam Padi Indonesia}

Berdasarkan amanat konstitusi di Indonesia yang termaktub dalam alinea keempat Pembukaan UUD 1945 dan sila kelima Pancasilan, semua peraturan perundangan di Indonesia harus mendukung terwujudnya negara kesejahteraan bagi seluruh rakyat Indonesia. Namun kenyataannya, keberpihakan hukum terhadap kesejahteraan rakyat dan dan warga negara yang miskin masih berada dalam tataran retorika politik di kalangan elit politik. ${ }^{30}$

Kelompok Hegelian ${ }^{31}$-Marxist ${ }^{32}$ memandang bahwa hukum sama dengan alat yg mengandung mistifikasi (membingungkan \& manipulatif) dan

${ }^{29}$ Assiter, A 1984, Althusser and structuralism, dalam The British journal of sociology, vol. 35, no. 2, Blackwell Publishing, hal. 272-296, yang dikutip dalam $<$ http://en.wikipedia.org/wiki/Structuralism>, diakses tanggal 19 Oktober 2011.

${ }^{30}$ Yohanes Suhardin, Peranan Negara dan Hukum dalam Memberantas Kemiskinan dengan Mewujudkan Kesejahteraan Umum, "Jurnal Hukum dan Pembangunan", tahun ke-40, no. 3 (Juli 2010), hal. 394--397.

${ }^{31}$ Dalam The Philosophy of Right, Hegel menguraikan filsafat sosial dan politik yang melihat kehidupan sosial modern berlangsung dalam 3 jagat utama, keluarga,masyarakat sipil dan negara. Kehidupan keluarga, ditandai dengan hubungan cinta dan kewajiban, sangat berlawanan dengan kehidupan di masyarakat sipil - jagat hubungan pertukaran ekonomi yang perburuan kepentingan diri murninya memungkinkan perwujudan atas apa yang disebut Hegel sebagai subjective particularity (individualitas, via produksi dan konsumsi) yang jelas-jelas mengkhianati karakter sosial mendalam (via pembagian tenaga kerja, spesialisasi, dan sistem kebutuhan) yang menjadi ciri kehidupan ekonomi modern (kapitalis). Hidup dalam keluarga dan hidup dalam maysrakat sipil dimungkinkan dan diwadahi dalam konteks hukum dan peraturan lebih luas melalui "negara administratif" (apa yang biasa kita sebut sebagai pemerintahan). Konsep state proper sebagai komunitas etis mencakup jagat hidup keluarga, mayarakat sipil dan administrasi negara, lihat Ritu Vij, "G.W.F. Hegel" dalam Jenny Edkins dan Nick Vaughan-Williams (editor), "Teori-Teori Kritis Menantang Pandangan Utama Studi Politik Internasional (Critical Theorist and International Relations)", terjemahan Teguh Wahyu Utomo, cet. I, Yogyakarta, Penerbit Baca!, 2010., hal. 225-226.

${ }^{32}$ Hegelian Marxism sering disebut dengan kelompok Critical Theory yang di dalamnya termasuk penganut Mazhab Frankfurt. Meskipun demikian, menjadi keliru kalau mencukupkan Hegelian Marxist dengan penganut Madzhab Frankfurt saja. Lihat Ralph Dumain, "On Hegelian Marxism, The Frankfurt School, And Van Gelder", rdumain at <igc.apc.org> dan dikutip dalam <http://www.srcf.ucam.org/pipermail/theory-frankfurt-school/1995-October/ 000114.html>, diakses tanggal 19 Oktober 2011. Kelompok Marxist Rudolf Hilferding menawarkan istilah kapitalisme terorganisir untuk menjabarkan hubungan negara dengan 
mendatangkan dampak yg berbeda bagi kelompok-kelompok yg berbeda. ${ }^{33}$ Betul-betul membingungkan ketika aturan-aturan tentang impor beras yang secara eksplisit ditujukan untuk memenuhi ketahanan pangan, ternyata malah menjadi salah satu penyumbang melemahnya ketahanan pangan dan bahkan menyebabkan menurunnya kesejahteraan petani. Secara teknis, ketahanan pangan pada tingkat nasional melemah karena beberapa faktor, yaitu (1) menurunnya jumlah dan mutu sumber daya alam, terutama sumber daya air yang menjadi modal utama pertanian pangan, (2) perubahan iklim dan dampaknya pada produksi bahan pangan, (3) prasarana distribusi yang tidak memadai terutama di daerah terpencil, (4) peraturan yang tidak memadai yang menjamin sistem dan distribusi perdagangan yang jujur, bertanggung jawab dan aman (termasuk impor beras) dan (5) besarnya jumlah penduduk yang belum mampu merasakan ketahanan pangan mereka sendiri. ${ }^{34}$

Pada bulan November 1996, pemerintah Indonesia turut hadir dalam Konferensi Tingkat Tinggi Pangan Sedunia yang diselenggarakan oleh FAO, yang kemudian mengakui bahwa pangan merupakan hak yang paling asasi. Di tahun yang sama, pemerintah Indonesia mengesahkan Undang-Undang Nomor 7 Tahun 1996 tentang Pangan. Ironisnya, setelah lebih dari lima belas tahun Undang-Undang Pangan disahkan, ternyata negara masih gagal memenuhi hak atas pangan warga negaranya. Terbukti, tragedi gizi buruk dan busung lapar yang membawa kematian masih saja terjadi di beberapa daerah di Indonesia. Akan tetapi, media yang memberitakan adanya kematian akibat busung lapar dibantah oleh Pemerintah dengan mengatakan bahwa yang bersangkutan meninggal karena penyakit yang lain. Unicef pernah mengumumkan bahwa balita yang mengalami kekurangan gizi di Indonesia meningkat 1,8 juta pada tahun 2005 menjadi 2,3 juta pada tahun 2006. Selain itu, ada 4 juta anak mengalami kekurangan gizi dan sekitar 10\% dari anak-anak tersebut meninggal dunia. $^{35}$

Pangan sebagai salah satu jenis yang mempengaruhi hajat hidup orang banyak, ternyata diperlakukan sebagai komoditi ekonomi semata. Logika

masyarakat. Claus Offe mendiskusikannya sebagai kapitalisme tak terorganisir dengan mengakui bahwa kapitalisme membutuhkan intervensi negara untuk membentengi dan mencegah kecenderungan krisis struktural, lihat Ben Agger, Teori Sosial Kritis, Kritik, Penerapan dan Implikasinya (Critical Social Theories: An Introduction), terjemahan Nurhadi, cet. VI, (Yogyakarta: Kreasi Wacana, 2009), hal. 344-345.

${ }^{33}$ Nurhasan Ismail, "Bahan Kuliah Sosiologi Hukum Bagi Magister Hukum UGM", dipublikasikan terbatas dalam bentuk file power point, hal. 32 .

${ }^{34}$ Lihat N. Pribadi , "Kehijakan Nasional Pemantapan Ketahanan Pangan" makalah pada Lokakaya Ketahanan Pangan Nasional, Yayasan Lembaga Konsumen Indonesia (YLKI) dan Consumers International Regional Office for Asian and the Pasific (CIROAP), Jakarta, 2829 Agustus 2001, yang dikutip dalam Hira Jhamtani, "Lumbung Pangan: Menata Ulang Kebijakan Pangan", editor Roem Topatimasang, cet. I. (Yogyakarta: INSIST Press, 2008), hal. 9

${ }^{35}$ Kompas, 11 Oktober 2006, yang dikutip dalam Hira Jhamtani, Lumbung Pangan: Menata Ulang Kebijakan Pangan, ..., hal. 9. 
berpikir ini yang dianut Undang-Undang Pangan karena lebih memprioritaskan perlindungan dan memfasilitasi para pengusaha pangan agar dapat memproduksi komoditi sesuai standar international ketimbang perlindungan, pemenuhan, pemajuan dan penghormatan hak atas pangan masyarakat. Perihal kekerasan modal, kasus-kasusnya dapat tercermin dari beberapa pengaduan yang diterima Komnas HAM. Semisal, perihal rekayasa genetika (kasus PT. Sanghyang Seri, kasus Monsanto, Kapas Transgenik), kemasan (kasus halal versus tidak halal), dan kasus impor beras (kasus petani yang dirugikan akibat impor beras). ${ }^{36}$

Sebagai upaya mewujudkan ketahanan pangan, Undang-Undang Pangan (Pasal 46-49) menyebut beberapa langkah. Pertama, mewujudkan cadangan pangan nasional; Kedua, penyediaan, pengadaan dan atau penyaluran pangan tertentu yang bersifat pokok; Ketiga, kebijakan mutu pangan nasional dan penganekaragaman pangan; Keempat, mencegah atau menanggulangi gejala kekurangan pangan; Kelima, memberikan kesempatan bagi koperasi dan swasta mewujudkan cadangan pangan; Keenam, pengembangan dan peningkatan partisipasi masyarakat di bidang pangan; Ketujuh, penelitian dan pengembangan teknologi di bidang pangan; Kedelapan, penyebarluasan dan penyuluhan pangan; Kesembilan, kerja sama internasional di bidang pangan; Kesepuluh, penganekaragaman konsumsi masyarakat. Langkah-langkah tersebut ditambah pula dengan peraturan teknis sebagaimana mandat Pasal 50 UU 7/1996, yaitu Peraturan Pemerintah Nomor 68 Tahun 2002 tentang Ketahanan Pangan. Pasal 2 ayat 2 PP ini menyebut tentang mekanisme untuk mewujudkan penyediaan pangan. Isinya, poin-poin yang terdapat tentang Ketahanan Pangan dalam Peraturan Pemerintah ini mengisyaratkan revitalisasi atau pembaruan metode pertanian. ${ }^{37}$

Ketahanan pangan sebagai disebutkan dalam UU No. 7 tahun 1996, adalah kondisi terpenuhinya pangan bagi rumah tangga yang tercemin dari tersedianya pangan yang cukup, baik jumlah maupun mutunya, aman, merata, dan terjangkau. ${ }^{38}$ Ketahanan pangan bukan sekedar masalah produksi, tetapi juga soal akses masyarakat kepada pangan, ketersediaan dan harga yang terjangkau, selain ada tidaknya keswasebadaan pangan di tingkat komunitas. ${ }^{39}$

Dalam rangka mengendalikan stabilitas harga pasar dan ketersediaan bahan pangan pada tingkat konsumen, pemerintah membentuk Bulog pada tahun 1967. Sampai pada pertengahan dasawarsa 1990-an, Bulog masih mengendalikan harga dasar dan harga eceran tertinggi beras. Bulog melakukan perpaduan berbagai alat kebijakan yang berupa monopoli perdagangan

\footnotetext{
${ }^{36}<$ http://taufiqulmujib.wordpress.com/2010/01/23/menyoal-undang-undang-pangan/>, diakses tanggal 19 Oktober 2011.

$37<$ http://taufiqulmujib.wordpress.com/2010/01/23/menyoal-undang-undang-pangan/>, diakses tanggal 19 Oktober 2011.

${ }^{38}$ Bab I Pasal 1 poin 17 UU No, 7 tahun 1986 tentang Pangan.

${ }^{39}$ Hira Jhamtani, loc. cit, hal. 36.
} 
internasional beras, akses kredit yang tidak terbatas jumlahnya, pembelian beras sebanyak mungkin oleh Depot Logistik (Dolog-jaringan pergudangan Bulog di daerah) untuk mendongkrak harga pasar, khususnya di pedesaan, dan sarana logistik yang tersebar luas. ${ }^{40}$ Peran publik Bulog tersebut kemudian berubah, monopoli perdagangan dan stabilisasi harga bahan pangan oleh Bulog dihapus berdasarkan Memorandum of Economics and Financial Policies yang ditandatangani pada awal tahun 1998 antara Indonesia dengan IMF. ${ }^{41}$

Dari sisi operasional BULOG, terdapat tiga saluran dalam penyerapan produksi petani yaitu Satgas, Unit Pengolahan Gabah dan Beras (UPGB) dan Mitra Kerja. Ketiga saluran tersebut membali gabah langsung pada petani dengan patokan Harga Pembelian Pemerintah(HPP). Umumnya gabah yang dibeli adalah gabah pada kualitas apa adanya (di luar kualitas yang ada dalam Inpres). Sedangkan gabah yang diterima BULOG adalah Gabah Kering Giling (GKG) yaitu gabah dengan kualitas kadar air maksimum 14\% dan kadar hampa kotoran maksimum 3\%. Kualitas ini cukup tahan disimpan dalam waktu tertentu dan siap digiling untuk menghasilkan beras standar pada saatnya. Dalam Inpres Nomor 7 Tahun 2009 pada tanggal 29 Desember 2010 dan berlaku per Januari 2010, harga GKG di tingkat penggilingan adalah Rp.3.300/kg dan di gudang BULOG Rp.3.345/kg. ${ }^{42}$

Satgas yang tidak memiliki sarana pengeringan maupun pengolahan dapat bekerjasama dengan UPGB atau Mitra Kerja melakukan pengolahan baik untuk mendapatkan GKG maupun beras standar. Dalam Inpres Nomor 7 tahun 2009 persyaratan kualitas beras yang diterima BULOG adalah beras dengan kadar air maksimal 14\%, butir patah maksimum 20\%, butir menir maksimum $2 \%$ dan derajat sosoh minimal 95\%. Beras dengan kualitas tersebut diterima BULOG dengan harga Rp.5.060/kg di gudang BULOG. ${ }^{43}$

Pada bulan Januari 2000, impor beras sepenuhnya diliberalisasi dengan bea impor sebesar 30\%. Impor beras dilakukan pemerintah untuk menambah jumlah sediaan dalam rangka menurunkan harga beras di pasar. Namun demikian, impor beras justu membuat semakin besarnya ketergantungan pada bahan pangan impor dan petani dalam negeri harus bersaing dengan banjirnya bahan pangan impor tanpa ada masa peralihan atau mekanisme pengaman, dan harga beras menjadi semakin fluktuatif. ${ }^{44}$ Menteri Perdagangan, Mari Elka Pangestu, mengatakan pemerintah akan memperpanjang kesepakatan kerja sama perdagangan beras dengan pemerintah Thailand.

${ }^{40} \mathrm{P}$ Timmer, "Food Secuity in Indonesia Current Chalenges and the Long-Run Out Look", Center for Global Development, Working Paper Number 48, Nopember 2004., yang dikutip dalam Hira Jhamtani, loc. cit, hal. 86-88.

${ }^{41}$ Hira Jhamtani, loc. cit, hal. 88.

${ }^{42}<$ http://www.bulog.co.id/alurada_v2.php>, diakses tanggal 16 Novermber 2011.

${ }^{43}$ Ibid.

${ }^{44}$ Hira Jhamtani, loc. cit, hal. 89. 
Nota kesepahaman yang dibuat berisi kesepakatan kerjasama pengadaan beras sebanyak 1,5 juta ton antara kedua negara yang dibuat tahun 2007 dan diperpanjang tiga tahun lalu. Pembicaraan mengenai perbaruan nota kesepahaman pengadaan beras dengan Thailand, kemungkinan akan dilakukan bersamaan dengan pembahasan kesepakatan perdagangan bilateral antar menteri kedua negara dalam tahun 2010. Menteri Perdagangan menambahkan pemerintah juga berencana memperpanjang kerjasama pengadaan beras dengan pemerintah Vietnam. Pembicaraan mengenai masalah itu, menurut Direktur Jenderal Kerjasama Perdagangan Internasional Kementerian Perdagangan Gusmardi Bustami kemungkinan dilakukan antara bulan Januari sampai Februari tahun $2011 .^{45}$

\section{Suara Sebagian Petani tentang Kebijakan Perberasan dan Impor Beras}

Terkait kesejahteraan petani dengan kebijakan harga gabah/beras, Himpunan Kerukunan Tani Indonesia (HKTI) di bawah kepemimpinan Oesman Sapta mengusulkan agar pemerintah menaikkan Harga Pembelian Pemerintah (HPP) terhadap gabah dan beras petani. Ketua Harian HKTI Sutrisno Iwantono mengakui, dengan kebijakan HPP saat ini, Bulog hanya mampu membeli beras petani jika harga pasar di bawah HPP. Sebaliknya, jika di atas maka perusahaan milik pemerintah tersebut kesulitan untuk menyerapnya. Oleh karena itu, pemerintah seharusnya kembali menggunakan harga dasar gabah (HDG) sehingga Bulog bisa membeli gabah maupun beras petani dengan harga berapapun dan lebih fleksibel. Selain itu, untuk menjaga stabilitas harga beras di pasaran agar tidak memberatkan konsumen jika terjadi kenaikan yang tinggi, maka pemerintah juga harus menerapkan harga eceren tertinggi. Sementara itu Sekjen HKTI Benny Pasaribu menyatakan, sudah sewajarnya jika pemerintah memberikan subsidi beras untuk membantu petani produsen. Dia mencontohkan di Jepang, pemerintah membeli beras petani seharga Rp40.000 per kg lebih tinggi dari beras impor yang rata-rata hanya sekitar Rp5.000 per kg. ${ }^{46}$

Terkait dengan impor beras, Dewan Pengurus Pusat (DPP) Serikat Petani Indonesia (SPI) menolak rencana pemerintah membuka keran impor karena akan berdampak sangat buruk bagi pertanian padi dan bukan solusi untuk mengantisipasi ancaman kekurangan stok nasional. "Impor beras malah akan melemahkan kemampuan untuk memastikan ketersediaan pangan dalam negeri karena Indonesia akan terperangkap dalam spekulasi perdagangan pangan dunia," ungkap Ketua Umum DPP SPI Henry Saragih. Impor beras akan sangat menekan produksi pangan yang dilakukan oleh para petani dan pada

$45 \quad<$ http://www.republika.co.id/berita/breaking-news/ekonomi/10/09/30/137403rithailand-perpanjang-kerja-sama-perdagangan-beras $>$, diakses tanggal 16 Novermber 2011.

$46<$ http://www.metrotvnews.com/ekonomi/news/2010/12/22/37525/HKTI-UsulkanKenaikan-HPP-Beras>, diakses tanggal 16 Novermber 2011. 
akhirnya komoditas beras akan bernasib sama dengan komoditas peternakan pertanian lain. Selama ini, komoditas tersebut dipasok dari luar negeri meskipun dapat ditanam atau diproduksi dengan baik di Indonesia, seperti kacang kedelai, susu, daging, dan tepung terigu. ${ }^{47}$

Selain itu, menurut Henry, impor beras akan menghabiskan banyak devisa negara. Anggaran yang harus dikeluarkan oleh pemerintah untuk mengimpor komoditas nonberas mencapai US\$5 miliar per tahun. "Karena itu kami menganggap rencana kebijakan impor beras ini menunjukkan Pemerintah telah gagal menyiapkan ketersediaan pangan nasional," tegasnya. Padahal, pemerintah dapat mengeluarkan berbagai kebijakan yang efektif untuk masalah ini, seperti dengan mengintegrasikan pasokan beras yang ada pada petani dan masyarakat. Pemerintah juga dapat mengintegrasikan beras yang ada di tangan para spekulan agar dapat dikelola oleh Perum Bulog. "Tarik beras dari para spekulan, dengan mengeluarkan Keppres misalnya, supaya mereka tidak terusterusan melakukan penimbunan beras", kata Henry ${ }^{48}$.

Ketahanan pangan harus dilihat sebagai suatu sistem. Dari segi ekonomi, ketahanan pangan terdiri dari tiga subsistem yang saling terkait, pasokan, distribusi dan konsumsi. Dari segi kelembagaan, ketahanan pangan tercapai melalui sinergi antara subsistem individu atau keluarga, subsistem masyarakat dan subsistem pemerintah. Mekanisme subsistem tersebut dihubungkan dengan berbagai aspek pembangunan lain seperti pertanian, transportasi, teknologi, sumber daya alam dan lingkungan, perdagangan, kesehatan dan pendidikan. ${ }^{4}$ Ketahanan pangan seharusnya menjadi idealitas yang menyejahterakan seluruh masyarakat yang berdaulat atas pangan di negerinya sendiri.

\section{Penutup}

Peraturan-peraturan yang mendukung kebijakan pemerintah untuk melakukan impor beras di Indonesia, selalu dikaitkan dengan persoalan ketersediaan dan ketahanan pangan. Kenyataan tentang semakin menurunnya angka ketahanan pangan dan kemiskinan yang diderita mayoritas petani di Indonesia, menjadi realitas paradoks dengan semua tujuan yang menjadi retorika dari keluarnya peraturan tersebut. Berdasarkan realitas ketidaksejahteraan yang semakin meningkat, maka semua peraturan tentang impor beras harus direvisi, karena tidak mendukung tujuan negara

$47<$ http://www.fsp2ki.org/index.php?option=com_content\&view=article\&id=232: serikat-petani-indonesia-tolak-impor-beras\&catid $=23$ :berita-oktober \&Itemid $=3>, \quad$ diakses tanggal 16 Novermber 2011.

${ }^{48} \mathrm{Ibid}$

49 N. Pribadi, Kebijakan Nasional Pemantapan Ketahanan Pangan, makalah pada Lokakaya Ketahanan Pangan Nasional, Yayasan Lembaga Konsumen Indonesia (YLKI) dan Consumers International Regional Office for Asian and the Pasific (CIROAP), Jakarta, 28-29 Agustus 2001, yang dikutip dalam Hira Jhamtani, loc. Cit., hal. 74. 
kesejahteraan Indonesia, sebagaimana yang diamanatkan UUD 1945 dan Pancasila. 


\section{Daftar Pustaka}

\section{Buku}

Agger, Ben. Teori Sosial Kritis, Kritik, Penerapan dan Implikasinya (Critical Social Theories: An Introduction), terjemahan Nurhadi, cet. VI, Yogyakarta: Kreasi Wacana, 2009.

Bottomore, Tom. Structuralism, dalam William Outhwaite (ed.), Kamus Lengkap Pemikian Sosial Modern (The Blckwell Dictionary of Modern Social Thought), Ed. 2. Cet. 1, Jakarta: Kencana 2008.

Deleuze, Gilles, How Do We Recognise Structuralism? dalam Desert Islands and Other Texts 1953-1974. penerjemah. David Lapoujade., Editor. Michael Taormina. Los Angeles and New York: Semiotext(e): 2004.

Jhamtani, Hira. Lumbung Pangan: Menata Ulang Kebijakan Pangan, editor Roem Topatimasang, cet. I. Yogyakarta: INSIST Press, 2008.

Vij, Ritu. "G.W.F. Hegel" dalam Jenny Edkins dan Nick Vaughan-Williams (editor), Teori-Teori Kritis Menantang Pandangan Utama Studi Politik Internasional (Critical Theorist and International Relations), terjemahan Teguh Wahyu Utomo, cet. I, Yogyakarta: Penerbit Baca!, 2010 .

\section{Jurnal/Makalah/Bahan Kuliah}

Assiter, A. "Althusser and Structuralism", dalam The British Journal of Sociology, vol. 35, no. 2, Blackwell Publishing, 1984.

Pribadi, N. "Kebijakan Nasional Pemantapan Ketahanan Pangan", makalah pada Lokakaya Ketahanan Pangan Nasional, Yayasan Lembaga Konsumen Indonesia (YLKI) dan Consumers International Regional Office for Asian and the Pasific (CIROAP), Jakarta, 28-29 Agustus 2001.

Ismail, Nurhasan. "Bahan Kuliah Sosiologi Hukum Bagi Magister Hukum $U G M$ ", dipublikasikan terbatas dalam bentuk file power point.

Suhardin, Yohanes. "Peranan Negara dan Hukum dalam Memberantas Kemiskinan dengan Mewujudkan Kesejahteraan Umum", Jurnal Hukum dan Pembangunan, tahun ke-40, no. 3, Juli 2010.

Timmer, P. "Food Secuity in Indonesia Current Chalenges and the Long-Run Out Look", Center for Global Development, Working Paper Number 48, Nopember 2004. 


\section{Internet}

$<$ http://arsipberita.com/show/impor-beras-bulan-ini-capai-500-ribu-ton120642.html>, diakses tanggal 24 November 2011.

$<$ http://arsipberita.com/show/bulog-masih-bayar-bea-impor-beras-rp450per-kg-122300. html>, diakses tanggal 24 November 2011.

$<$ http://arsipberita.com/show/mentan-impor-beras-untuk-jaga-stabilitaspangan-118997.html>, diakses tanggal 24 November 2011.

$<$ http://en.wikipedia.org/wiki/Structuralism>, diakses tanggal 19 Oktober 2011.

$<$ http://taufiqulmujib.wordpress.com/2010/01/23/menyoal-undangundang-pangan/>, diakses tanggal 19 Oktober 2011.

$<$ http://www.bulog.co.id/alurada_v2.php $>$, diakses tanggal 16 November 2011.

$<$ http://www.fsp2ki.org/index.php?option=com_content\&view=article\&i $\mathrm{d}=232$ : serikat-petani-indonesia-tolak-impor-beras\&catid $=23$ :beritaoktober\&Itemid=3>, diakses tanggal 16 November 2011 .

$<$ http://www.metrotvnews.com/ekonomi/news/2010/12/22/37525/HKTIUsulkan-Kenaikan-HPP-Beras>, diakses tanggal 19 Oktober 2011.

$<$ http://www.republika.co.id/berita/breaking-news/ekonomi/10/09/30/ 137403-rithailand-perpanjang-kerja-sama-perdagangan-beras $>$, diakses tanggal 19 Oktober 2011.

Dumain, Ralph. "On Hegelian Marxism, The Frankfurt School, And Van Gelder", rdumain at igc.apc.org dalam <http://www.srcf.ucam.org/ pipermail/theory-frankfurt-school/1995-October/000114.html>, diakses tanggal 19 Oktober 2011.

Lemlit UGM, "Ketahanan Pangan", <lemlit.ugm.ac.id/Agro/download/ white_paper.doc>, diakses tanggal 24 November 2011.

\section{Peraturan}

Peraturan Presiden RI No. 83 tahun 2006 Tentang Dewan Ketahanan Pangan.

Peraturan Menteri Perdagangan RI No. 12 tahun 2008 Tentang Ketentuan Impor. 